\title{
Aikuiskasvatustieteellinen tutkimus Helsingin yliopistossa
}

\section{ASTEITTAIN KOHTI LAAJOJA TUTKIMUSOHJELMIA}

Tarkastelen aikuiskasvatustieteellistä tutkimusta erityisesti oman laitoksemme, Helsingin yliopiston kasvatustieteen laitoksen näkökulmasta.

\section{Aikuiskasvatustieteellisen tutkimuksen ja opetuksen profiloituminen}

Kasvatustieteellinen tutkimus on yleisemminkin kohdistunut aikuiskoulutukseen tai sivunnut aikuisia oppijoina. Tutkimuksen profiloituminen aikuiskasvatukseen on tapahtunut asteittain ja korostunut aikuiskasvatuksen arvosanaopetuksen ja myöhemmin aikuiskasvatuksen/koulutuksen koulutusohjelmien perustamisen myötä.

Aikuiskasvatuksen arvosanaopetus käynnistyi Helsingin yliopistossa lukuvuonna 1977-78. Sitä ennen oli kasvatustieteen ruotsinkielisen oppituolin haltija professori Peep Koort jo 1960-luvulta lähtien tuonut aikuiskasvatuksen oppisisältöjä laitoksen tutkimukseen ja opetusohjelmiin. Vuonna 1980 perustettiin aikuiskoulutuksen oppituoli Helsingin yliopistoon ja samaan aikaan aikuiskasvatus nousi kasvatustieteen rinnalle omaksi suuntautumisvaihtoehdokseen. Eriytyminen jatkui siten, että vuonna 1987 käynnistyi aikuiskoulutuksen koulutusohjelma. Kun kasvatusalan tutkinnoista säädetty asetus astui voimaan 1.8.1995, koulutusohjelmista on luovuttu ja siirrytty takaisin arvosanaopetukseen. Tämä muutos merkitsee Helsingin yliopiston kasvatustieteen laitoksella sitä, että meillä on erilliset, mutta osin keskenään integroidut (esim. tutkimusmenetelmien opiskelu) arvosanaopinnot sekä kasvatustieteessä että aikuiskasvatustieteessä. Opetusta annetaan molemmissa oppiaineissa myös ruotsinkielisenä.

Alan tutkimus on lähtenyt Helsingin yliopiston kasvatustieteen laitoksella liikkeelle pitkälti yksittäisten tutkijoiden omien intressien pohjalta, mutta se on asteittain suuntautunut laajempiin projekteihin ja tutkimusohjelmiin. Esimerkkinä tutkimuksen profiloitumisesta on toiminnan teorian ja kehittävän työntutkimuksen alue, jolle on laitoksella perustettu vuonna 1994 oma tutkimusyksikkönsä. Tätä suuntausta tukee myös laitoksella vuoden 1995 alussa käynnistynyt kehittävän työntutkimuksen ja aikuiskoulutuksen tohtorikoulutusohjelma, jota johtaa akatemiaprofessori Yrjö Engeström. Tämän lisäksi on teoreettisilta lähtökodiltaan erilaisia projekteja ja yksittäisten tutkijoiden tutkimushankkeita. Samoin suuntaus kansainväliseen tutkijayhteistyöhön on korostumassa.

\section{Yliopisto-opiskelu tutkijakoulutusta}

Aikuiskasvatustieteen opiskelu on alan asiantuntijoiden ja tutkijoiden koulutusta. Akateemisessa opiskelussa korostuu tutkijavalmiuksien kehittyminen sisällöllisten kysymysten tarkastelujen ohessa. Tutkimusalueen perustieteinä voidaan pitää lähinnä sosiologiaa ja psykologiatieteitä. Aikuiskasvatustieteelle on ominaista, että aikuista ja hänen toimintaansa tarkastellaan ja tutkitaan hänen omassa sosiaalisessa kontekstissaan. Aikuiskasvatustieteellinen lähestymistapa korostaakin toiminnan kontekstisidonnaisuutta. Tämä näkyy myös alan tutkimuksessa ja menetelmäkoulutuksessa.

Vielä 1970-luvun puolella kasvatustieteellinen tutkimus oli varsin yleisesti kvantitatiivista tutkimusta. Aikuiskasvatustieteellinen tutkimus oli luonnollisesti alkuvaiheissaan osin sidottu tähän kehitystrendiin. 
Erityisesti aikuisen oppimisen ja muun toiminnan näkeminen laajemmassa viitekehyksessä on korostanut laadullisten menetelmien tärkeyttä alan tutkimuksessa. Laajemminkin on kysymys pyrkimyksestä siirtyä toteavasta ja yleistyksiä tavoittelevasta tutkimusperinteestä ilmiöitä ymmärtävään suuntaan. Yliopisto-opiskelussa hankitaan valmiuksia sekä kvalitatiivisten että kvantitatiivisten menetelmien käytössä. Tutkimuksen luonne kulloinkin sanelee niiden käytön mielekkyyden. joissakin tilanteissa on hyväksi käyttää erilaisia tiedonhankinnan ja analyysien tapoja toisiaan täydentävästi kattavamman kuvan luomiseksi tutkittavasta ilmiöstä. Tämäntyyppisestä otteesta on jo joitakin näyttöjä. Menetelmävalintoja suuntaavat luonnollisesti myös tutkimuksen tieteenfilosofiset lähtökohdat ja tutkimuksen paradigmaattiset sidokset.

Sisällöllisesti opintoihin on kuulunut $\mathrm{mm}$. kaksi toisiaan täydentävää aluetta, joista toinen liittyy aikuiskoulutuksen yhteiskunnallisiin kytkentöihin ja organisaatioanalyyseihin sekä toinen aikuisen oppimiseen ja sen psykologisiin perusteisiin. Opinnoissa on pyritty korostamaan teorian ja käytännön keskinäisten suhteiden tarkastelua. Opiskelijoiden tekemät sivuainevalinnat osaltaan suuntaavat yksilötasolla oman asiantuntijuuden kehittymistä. Ne opiskelijat, jotka suuntautuvat erityisesti opetustehtäviin, voivat nykyisin halutessaan liittää maisterin tutkintoonsa opettajankelpoisuuden tuottavat opinnot.

\section{Tutkimustoiminta}

Aikuiskasvatustieteellinen tutkimus voi olla luonteeltaan sekä soveltavaa että perustutkimusta. Perustutkimuksen tehtävänä on tuottaa uusia tapoja tutkia erilaisia ilmiötä. Laitoksellamme voidaan katsoa perustutkimuksen alueelle sijoittuviksi esimerkiksi kehittävä työntutkimus (Engeström), dynaamisen käsiteanalyysin kehittäminen kompleksisten ilmiöiden tutkimukseen (Kontiainen) ja systemaattisen analyysin kehittäminen sisällönanalyyttisiä tutkimuksia varten (Nurmi). Mainitut tutkimusotteet ovat johtaneet moniin sovelluksiin erilaisissa tutkimushankkeissa. Kaksi ensin mainittua on löytänyt tiensä myös tutkimuskäyttöön ulkomailla.

Laitoksen aikuiskoulutuksen tutkimustoiminnasta pyrin antamaan yleiskuvan seuraavassa. Tutkimus painottuu mm. työelämän aikuiskoulutukseen, henkilöstökoulutukseen ja organisaation kehittämiseen, aikuisen oppimiseen, koulutuksen arviointiin, monimuoto-opiskeluun ja aikuisen oppimisen kulttuurisiin kysymyksiin. Useat tutkimukset liittyvät myös avoimeen yliopistoon ja täydennyskoulutukseen. Vaikka edellä esitetyt, laitoksen piirissä kehitetyt tutkimukselliset lähestymistavat omalta osaltaan suuntaavat tutkimustoimintaa, kokonaisuudessaan se sisältää erilaisia menetelmävalintoja ja lähestymistapoja. Yleisenä pyrkimyksenä voitaneen pitää sitä, että tutkimuksellisin keinoin päästään ymmärtämään aikuiskoulutuksen kehityslinjoja ja aikuisen arkitodellisuutta sekä ymmärtämään ja mahdollisuuksien mukaan suuntaamaan näihin liittyviä muutosprosesseja tuottamalla erilaisia muutosvaihtoehtoja.

\section{Opinnäytetutkimus}

Edellä kuvattu arvosanaopetuksen asteittainen laajentaminen näkyy tutkimustyön alueella selvimmin vuodesta 1985 alkaen. Uuden opetus- ja tutkimusalan käynnistäminen vie luonnollisesti useita vuosia. Tämä koskee erityisesti alan tutkimusta. Lopussa on kootusti esitetty hyväksymisen ajankohdan mukaisessa järjestyksessä lisensiaatti- ja väitöskirjojen tekijät ja heidän tutkimusaiheensa vuosina 1985-95. (Ks. viite liitteen jälkeen). Liitteessä ei ole kuitenkaan mainittu monia kasvatustieteen puolelle sijoittuvia tutkimuksia, jotka aiheensa puolesta liittyvät aikuiskoulutuksen tai työelämän kenttään. Luettelosta, ennen muuta pro gradu -työt mukaan lukien, voidaan havaita, että tutkimuksissa on pureuduttu laajalti erilaisiin aiheisiin ja ilmiöihin. Opinnäytetutkimuksessa on erityisen tärkeää opiskelijan oma kiinnostus ja sitoutuminen tutkimusaiheeseensa. Monet ovat löytäneet tutkittavan ilmiönsä työtehtävistään tai opiskeluun kuuluvan työharjoittelun aikana. Luettelo osoittaa myös, että suhteellisen lyhyessä ajassa on määrällisesti ylletty kohtuulliselle tasolle. Käsitykseni mukaan tutkimukset ovat keskimäärin laadullisesti hyvää tasoa myös kansainvälisessä vertailussa. Monet opinnäytetutkimukset ansaitsisivat laajempaakin levikkiä kuin pelkän arkistokappaleen sijoittamista kirjaston hyllyyn. 
Tutkimusten yleisenä ja yhteisenä piirteenä voitaneen pitää pyrkimystä teorian ja käytännön yhdistämiseen ja tutkimuksen sitomista tiettyyn kontekstiin. Lähtökohdiltaan ja menetelmiltään tutkimukset ovat enemmän tai vähemmän toisistaan poikkeavia. Tietenkin voidaan aina kysyä, kuinka hyvin tutkimuksella on päästy jäsentämään ja analysoimaan tieteenalan ja kohdealueen kannalta keskeisiä kysymyksiä. Liitteessä esitetty aiheluettelo antanee pohjaa tehdä arviointeja yleisellä tasolla eri näkökulmista.

\section{Projektitutkimus}

Laitoksen laajin projektitoiminta perustuu toiminnan teorian ja kehittävän työntutkimuksen sovelluksiin interventiotutkimuksissa. Tältä pohjalta on toteutettu useita mittavia tutkimushankkeita (esim. terveyskeskusprojektit ja alioikeuksien kehittämishanke). Tutkimuksen monitieteellinen ja kansainvälinen leima on vahvistunut oman tutkimusyksikön ja kehittävän työntutkimuksen ja aikuiskoulutuksen tohtoriohjelman myötä. Yksittäisistä osatutkimuksista monet liittyvät työelämän tiimeihin, verkostoitumiseen ja innovaatioprosesseihin. Toiminnan teorian ja kehittävän työntutkimuksen yksikön tutkimustoiminta painottaa seuraavia alueita (suluissa koordinaattorit):

- Muutoksen hallinta oppivassa organisaatiossa: kognitio, yhteistoiminta ja asiantuntijuus tiimeissä ja verkostoissa (Yijö Engeström).

- Teknologiset ja organisatoriset innovaatiot teollisuudessa ja tutkimustyössä (Reijo Miettinen).

- Tietokoneutettu yhteistyö työtoiminnassa (Kari Kuutti).

- Sosiaali- ja terveyspalvelujen työprosessien ja organisaatioiden muutos (Kirsti Launis ja Osmo Saarelma).

- Muutoksen johtaminen organisaatioissa ja verkostoissa (Jaakko Virkkunen).

- Kotityön ja kotitalouden opetuksen kehittäminen (Terttu Gröbn).

Tällä hetkellä mittavin kehittävän työntutkimuksen projekti on Engeströmin johtama kansainvälinen vertaileva tutkimus "Oppiminen ja asiantuntijuus tiimeissä ja verkostoissa".

Seuraava luettelo Helsingin yliopiston kasvatustieteen laitoksen tutkimushankkeista antaa yleiskuvaa aikuiskoulutuksen muista projekteista ja tutkimusalueista (projektien johtajat on mainittu suluissa):

- Aikuisen oppimisen kulttuuriset yhteydet (Seppo Kontiainen, Jarkko Hautamäki ja Kari E. Nurmi). Osaprojektit: (1) tiedon olemus ja ongelmanratkaisu työssä, (2) aikuisen funktionaalinen lukutaidottomuus ja (3) maahanmuuttajien integroituminen suomalaiseen kulttuuriin.

- Aikuiskoulutuksen institutionalisoituminen ja avointen opiskelujärjestelmien muodostuminen/Akatemian koulutuksen vaikuttavuuden tutkimusohjelma (Seppo Kontiainen ja Kari E. Nurmi).

- Täydennyskoulutuksen laadullinen kehittäminen (Seppo Kontiainen ja Jyri Manninen).

- Yksityisyrittäjien työelämäkerrat ja ammatissa selviytyminen (Ritva Lindroos).

- Avoimet opiskeluympäristöt ja koulutuksen vaikuttavuus (Jyri Manninen).

- Tietokonevälitteinen viestintä monimuotoopiskelussa (Jyri Manninen).

- Opetuksen ja oppimateriaalien semiotiikka (Kari E. Nurmi).

- Pohjois-Karjalan oppilaitosten verkottuminen ja alueellisten oppimiskeskusten kehittämishanke (Urpo Sarala).

Edellä esitetyt luettelot antavat yleiskuvan tutkimusalueista ja niiden yhteydessä ei ole mainittu yksittäisiä tutkijoita, jotka monessa tapauksessa ovat samalla jatko-opiskelijoita. Samoin projektiluettelon ulkopuolelle jäävät monet laitoksen dosentit sekä ruotsinkielisen ohjelman ja kasvatustieteen tutkijat, jotka tekevät aikuiskoulutusta koskevaa tutkimusta.

\section{Kansainvälistyminen}

Tutkijoiden ja opettajien kansainvälinen yhteistyö on aikaisemmin rakentunut paljolti yksittäisten tutkijoiden toiminnan varaan. Aikuiskasvatustieteellistä tutkimusyhteistyötä on ollut erityisesti englantilaisten ja yhdysvaltalaisten tutkijoiden kanssa, mutta piiri on vähitellen laajentunut. Muutamat laitoksen tutkijat ovat työskennelleet välillä myös ulkomaisissa yliopistoissa. Euroopan unionin piirissä on suunnitteilla tai 
käynnistymässä kaksi-kolme yhteistä hanketta (esim. pict-kouluttajuuden kehittämiseen liittyvä hanke), joihin sisältyy myös tutkimusta. Opiskelijoiden osallistuminen EU:n vaihto-ohjelmiin tuottaa toivottavasti jatkossa luontevan pohjan rakentaa kansainvälistä tutkijayhteistyötä. Laitostasolla voidaan tehdä yhteistyösopimuksia, jotka luovat viitekehyksen yksittäisille tutkijoille ja tutkijaryhmille löytää omat toimivat verkostonsa.

Laitoksen tutkija (Jyri Manninen) on ollut mukana viiden eurooppalaisen yliopiston Euromove-projektissa, joka tutkii työvoiman liikkuvuutta EU-maiden välillä. Vertailevan tutkimuksen alueella kansainväliset kontaktit ja yhteistyö muodostuu tärkeäksi, esimerkkeinä edellä mainittu Engeströmin tutkimus sekä koulutuksen vaikuttavuus -projektiin liittyvä vertailututkimus (Englanti, Espanja ja Suomi) avoimen yliopiston mallien muotoutumisesta (Kari Kantasalmi). Samoin on tutkittu kansainvälistä etäopetuskokeilua (Irene Hein-Nieminen) yhteistyössä amerikkalaisen yliopiston kanssa. Aikuisen oppimisen kulttuuriset yhteydet -projektin piirissä on tutkittu mm. kehitysyhteistyöprojektiin liittyen egyptiläisiä kyläkätilöjä (Soila Juden-Tupakka) ja argentiinalaisia koulutusta vailla olevien työntekijöiden työtehtäviin liittyvää ongelmanratkaisua (Juan Carlos Llorente). Tunnustelevaa yhteistyötä on ollut myös Pietarin yliopiston tutkijoiden kanssa.

Kansainvälinen yhteistyö on johtanut $\mathrm{mm}$. yhteisiin julkaisuihin ja yhteiseen jatko-opiskelijoiden ohjaukseen. Lisäksi laitos on mukana Adult Education/ERASMUS vaihto-ohjelmassa.

\section{Keskustelua}

Tutkimuksen perustehtävänä on käsitteellisesti jäsentää ja luoda ymmärrystä tutkittavasta ilmiöstä ja etsiä keinoja muutosten hallintaan. Tutkimuksen tehtävänä on etsiä vastauksia asetettuihin kysymyksiin, tuottaa uusia kysymyksiä sekä tuottaa välineitä (teoriat, mallit, analyysivälineet) ilmiöiden ja arkitodellisuuden hahmottamiseksi.

Tämä kirjoitus esittelee aikuiskasvatustieteellistä tutkimusta erityisesti Helsingin yliopiston kasvatustieteen laitoksen suomenkielisen opetuksen suunnasta. Omalta osaltaan kirjoitus ehkä antaa kuvaa laajemminkin alan tutkimuksen painotuksista tällä hetkellä.

Kasvatusalalla on ollut tyypillistä yksin puurtavat tutkijat. Viime aikojen kehitys kohti laajempia projekteja on selvästi edistänyt tutkijoiden välistä yhteistyötä. Tämä luo pohjaa myös monitieteisten projektien synnylle. Tiimityöskentely on olennaista todellisessa kansainvälisessä tutkijayhteistyössä, joka toivottavasti lisää jatkossa myös suomalaisten tutkijoiden kansainvälistä julkaisutoimintaa. Samoin olisi toivottavaa, että usein raskaasta monografiasta siirryttäisiin enemmän artikkelityyppiseen tutkimusten raportointiin.

Opinnäytetutkimusten ja tutkimusprojektien kirjo osoittaa, että tutkimuksissa on varsin laajalti lähestytty aikuiskasvatuksen ja -koulutuksen kysymyksiä. Voidaan tietenkin kysyä, jääkö tässä vaiheessa jotakin olennaista näiden tutkimusten ulkopuolelle. Painopiste on tällä hetkellä vahvasti työelämässä ja koulutusinstituutioissa ja yleisemmin aikuisen oppimisen problematiikassa. Esimerkiksi vapaa sivistystyö on melko vähän tutkittu alue Helsingin yliopistossa, vaikka aikuisen oppimista koskevat tutkimukset sivuavat myös tätä kenttää. Koulutuksen talouteen liittyviä tutkimuksia ei juuri ole. Historiallisia tutkimuksia voisi olla enemmänkin. Tietysti voidaan samalla kysyä, tulisiko jokaisen yliopiston kattaa kaikki mahdolliset alueet vai voiko löytyä jonkinlaista väljää työnjakoa eri yliopistojen välillä. Uskoakseni työnjakoa on syntynytkin luonnollisesti erilaisten tutkimusintressien kautta.

Helsingin yliopisto

LISENSMATINTUTKIELMAT AIKUISKASVATUSTIETEESSA 1985-95

Varila, Juha (1985). Mitä on koettu koulutustarve? Koulutustarvetta ja erityisesti koettua koulutustarvetta kuvaavan ja selittävän käsitteistön jäsennys ja empiirinen sovellus. 
Lindroos, Ritva (1987). Osallistujakeskeisyys aikuiskoulutuksessa. Osallistujakeskeisyyden kommunikatiivista määrittelyä.

Launis, Kirsti (1988). Ongelmanratkaisun kehittäminen asiantuntijatyössä. Kehittävän työntutkimuksen sovellus Työterveyslaitoksen toksikologian koulutusohjelmassa.

Manninen Jyri (1991). Akateemisen työttömän elämäntilanne. Työvoimakoulutuksen kohderyhmäanalyysi.

Tarmo, Heljä (1992). Verohallinnon perehdyttämiskoulutus -perinteisestä koulutuksesta oppivaan organisaatioon.

Märkjärvi, Leila (1993). Päihderiippuvuuden kohtaaminen lähiyhteisössä. Tutkimus työterveyshoitajan päihdetyötoiminnasta myllyhoidollisen koulutusintervention jälkeen.

Ahteenmäki-Pelkonen, Leena (1993). Mezirowin käsitys aikuisopiskelijan itseohjautuvuudesta.

Llorente, Juan (1994). Constitution of Knowledge and Problem Solving at Work.

Paakkunainen, Ritva (1994). Yrityksen päätöksenteon oppiminen: Case-tutkimus Ravintolapelistä.

Saari, Eveliina (1994). Voidaanko tutkimusryhmiä perustaa? Tapaustutkimus Valtion teknillisen tutkimuskeskuksen metallilaboratorion ryhmäkokeilusta vuosina 1989-1991.

Vehviläinen, Sanna (1995). Psykodraaman vuorovaikutuksen rakentuminen. Etnometodologinen tarkastelu.

VÄ1TÖSKIRJAT AIKUISKASVATUSTIETEESSÄ 1986-95

Sarala, Urpo (1986). Henkilöstökoulutuksen mahdollisuudet teollisuusyrityksen kehittämisessä - tapausesimerkkinä ASKO-koulutusprojekti. Helsingin yliopiston kasvatustieteen laitoksen tutkimuksia 109.

Engeström, Yrjö (1987). Learning by expanding.. An activity-theoretical approach to developmental research Helsinki.. Orienta-Konsultit.

Varila, Juha (1989). Koetusta koulutustarpeesta ja sitä selittävistä tekijöistä. Koetun koulutustarpeen tarkastelu kolmesta koulutustarpeen arviointiperustasta ja näin ilmenneeseen koulutustarpeeseen vaikuttavista tekijöistä - tutkimuskohteena ammattiyhdistysluottamusmiehet. Helsingin yliopiston kasvatustieteen laitoksen tutkimuksia 121.

Lindroos, Ritva (1993). Työ, koulutus, elämänhallinta. Elämäkertatutkimus työllisyyskoulutukseen osallistuneiden työorientaatioista. Helsingin yliopiston kasvatustieteen laitoksen tutkimuksia 136

Manninen, Jyri (1993). Akateemiset työttömät työnhakijat. Elämäntilanne ja työvoimakoulutus. Helsingin yliopiston kasvatustieteen laitoksen tutkimuksia 137.

Launis, Kirsti (1995).Asiantuntijoiden yhteistyö perusterveydenhuollossa. Käsityksiä ja arkikäytäntöjä. Stakes: tutkimuksia 50.

Kyrö, Paula (1995). The Management Consulting Industry Modelled Through Profession. Department of Education, University of Helsinki, Res.Bulletin 87.

Pro gradu -töitä ei niiden suuren määrän vuoksi voitu kirjoittajan toivomuksesta huolimatta julkaista oheisessa liitteessä. Koska luettelo kuitenkin antaa havainnollisen kuvan opinnäytteiden sisällöllisestä laajuudesta, listan saa pyydettäessä tämän lehden toimituksesta. 